\title{
Müşterek Bir Hücum: Slav ve Avarların Selânik Kentine Saldırıları (617/618)
}

\section{A Joint Attack: The Attacks of the Slav and Avars on the City of Thessaloniki (617/618)}

\author{
Fatma İnce ${ }^{1}$ (1)
}

'Sorumlu yazar/Corresponding author: Fatma İnce (Doç. Dr.)

Inönü Üniversitesi, Fen-Edebiyat Fakültesi,

Tarih Bölümü, Malatya, Türkiye.

E-posta: fatma.ince@inonu.edu.tr

ORCID: 0000-0002-9820-4604

Başvuru/Submitted: 19.03.2021

Revizyon Talebi/Revision Requested: 27.03.2021

Son Revizyon/Last Revision Received: 29.03.2021

Kabul/Accepted: 30.03 .202

Atıf/Citation: Fatma Ince, "Müșterek Bir Hücum: Slav ve Avarların Selânik Kentine Saldırıları (617/618)", Güneydoğu Avrupa Araştırmaları Dergisi, 37 (2021), s. 1-16 https://doi.org/10.26650/gaad.900115

\section{öz}

Göktürklerin hükmü altına girmek istemeyen Avarlar, batıya doğru hareket etmişler ve Bizans Devleti'ne elçilerini göndererek, onlarla anlaşma yapmak istediklerini bildirmişlerdir. Bizans Devleti'nin ise bu sırada, düşmanları olan Bulgarlara ve Slavlara karşı kullanabilecekleri bir güce ihtiyaçları bulunmaktaydı. Bu sebeple Bizans İmparatoru I. Justinianos (527-565), Avarlar ile bir anlaşma imzalamıştır. Anlaşmaya göre, Bizans Devleti, Avarlara yıllık vergi ödeyecek, Avarlar da bunun karşlığında Bizans Devleti'nin düşmanlarına karşı mücadele edeceklerdir. Dostça başlayan Bizans-Avar münasebetleri, daha sonraki yıllarda, şartların da değişmesiyle farkıı bir hâl alacaktır. Nitekim Avarlar, II. Justinos (565-578) döneminden itibaren zaman zaman Bizanslıların düşmanı olan Slavlar ile menfaatlerine göre birlik tesis etmekten çekinmemişlerdir. Vuku bulan Slav-Avar ittifakının en büyük hedeflerinden biri Balkan toprakları üzerinedir. Balkanlar hem Slavlar ve Avarlar hem de Bizans Devleti açısından jeopolitik konumu itibariyle oldukça önemlidir. 565-616 yılları arasında Slav-Avar birlikleri gerçekleştirdikleri akınlarla bu bölgenin büyük bir kısmını ele geçirmelerine rağmen bölgenin en önemli merkezlerinden biri olan Selânik'in ele geçirilmesi mümkün olmamıştır. Bu çalışmada 617/618'de Slav-Avar kuvvetlerinin Selânik üzerine düzenlemiş oldukları hücümlar, kuşatma esnasında yaşanılanlar, kullanılan silâh ve teçhîzatlar ve vuku bulan saldırıların Bizans yanında Slav-Avar ittifakı açısından neticeleri Aziz Demetrios'un Mucizeleri isimli eser esas alınarak, değerlendirilecektir.

Anahtar Kelimeler: Avar, Slav, Bizans, Selânik, Aziz Demetrios, Mucizeler

\section{ABSTRACT}

The Avars, who did not want to fall under the rule of the Gokturks, moved west and sent their envoys to the Byzantine State, informing them that they wanted to conclude an agreement with them. Meanwhile, the Byzantine State needed a force that they could use against their enemies, the Bulgarians and Slavs. For this reason, the Byzantine Emperor lustinianos I (527-565) 
signed an agreement with the Avars. According to the agreement, the Byzantine State will pay annual taxes to the Avars, and in return the Avars will fight against the enemies of the Byzantine State. Byzantine-Avar relations, which began as friendly, will become different in the following years with the change of circumstances. As a matter of fact, the Avars did not hesitate to establish unity with the Slavs, who were the enemies of the Byzantines since the period of lustianos II (565-578), according to their interests. One of the main goals of the Slavic-Avar alliance is over the Balkan territory. The Balkans is very important for both Slavs, Avars and the Byzantine State in terms of its geopolitical position. Although Slav-Avar troops captured a large part of this region with their raids between the years 565-616, it was not possible to capture Thessaloniki, one of the most important centers of the region. In this study, the attacks organized by the Slavic-Avar forces on Thessaloniki in $617 / 618$, the events experienced during the siege, the weapons and equipment used, and the consequences of the attacks that occurred in terms of the Slavic-Avar alliance alongside Byzantium will be evaluated on the basis of the work named The Miracles of Saint Demetrios.

Keywords: Avar, Slav, Byzantine, Thessaloniki, Saint Demetrios, Miracles

\section{EXTENDED ABSTRACT}

Thessaloniki is one of the most important cities of the Roman period. The city has a very important place in the history of Christianity both because it is an important trading port of the Balkan Peninsula and because the Apostle Paulus visited the city. The city walls built during the time of Theodosius (347-395) are another factor that increases the importance of this city. Thessaloniki is the second important city after Constantinople in terms of the Byzantine State. Slavic-Avar troops organized many expeditions in various periods, especially on Thessaloniki, which they considered a key to the Mediterranean coast, but did not achieve any success in this regard.

The Avars will begin to play an active role in Eastern Europe and the Balkans, moving along the path opened by the Migration of Tribes in 558. During the mentioned period, the Byzantine State, on the one hand, was struggling with the socities remaining from the Huns and Slavs in the West, and Sâsânî in the East. Along with the entry of the Avars into Eastern Europe and the Balkans, the Byzantine State had to take measures against the Avars this time. After all, the Byzantine Emperor lustinianus I (527-565), who realized that he could not fight the Huns, Slavs, Avars and Persia at the same time agreed to pay taxes by making a deal with the Avars, and in response to this situation, the Avars would also side with the Byzantine State in possible struggles against the Bulgarians and Slavs.

On the occasion of this agreement with the Avars, the Byzantine State kept the Bulgarians, Slavs and other enemy elements under control and also got rid of the economic burden and loss of people that could arise if the expedition was organized against different external threats. However, since the time of lustinos II (565-578), the alliance between the two sides ended because Byzantium did not want to continue paying taxes to the Avars. In the later period, the Avars did not hesitate to be in unity with the Slavs, the enemy of Byzantium. As a result of the struggles, the Slav-Avar armies achieved their goal of holding in the Balkans to a large extent and seized many cities in the region. One city would remain independent from 
this situation: Thessaloniki. The attacks on the region by the Slav-Avar troops in 617/618 have a special place in Saint Demetrios' narratives.

According to the narration in The Miracles of Saint Demetrios, the Avars first sent scouts who were waiting for everyone outside the walls. The kagan came later, with the majority of his forces, including heavy siege vehicles, rams, catapults, and siege towers. Emperor Heraclius (610-641) was stunned by the Slav-Avar attack as he fought intensely against the Persians and could not send any aid to the city, and as a matter of fact, Thessaloniki had to rely on his own forces. However, the stories of the people of Nis and Sardica, who had previously experienced Slav-Avar attacks and fled to Thessaloniki, created great fear and anxiety on the people. However, despite this, especially with the encouragement of Archbishop loannes, the people of Thessaloniki will start to protect the city. It should be noted that the siege was much better organized than in previous attempts. As a result of a number of events that are considered to be a miracle by the people of Thessaloniki but seen as unlucky by the Slav-Avar armies, the siege will result in negativity for the Slav-Avar troops. Eventually, the Avar Khan reached a negotiated agreement with the Thessalonians and left the city. The Slavs sold their captives to the Thessaloniki people. The 33-day siege of Thessaloniki was an siege that ended in failure in 617 or 618 by Slavic tribes and Avars who settled near the city of Thessaloniki, the largest Byzantine fortress in the region. The alliance established, the weapons used, the state of the people, the developments during the siege of the city and the departure of the Slavic-Arab troops from Thessaloniki will be evaluated on the basis of a contemporary source, The Miracles of Saint Demetrios. 


\section{Müşterek Bir Hücum: Slav ve Avarların Selânik Kentine Saldırıları (617/618)}

\section{Selânik}

Yahudiler Selânik'i “şehirlerin anası”; Osmanlı coğrafyacıları ise “istanbul'un bir parçası" olarak tanımlamaktadırlar. Chontiats Dağlarının eteklerinde, muazzam bir tarım bölgesi olan ve aynı zamanda güvenli olduğu kadar geniş bir limana sahip olan Selânik, Makedonya Kralı Kassander (M.Ö. 395-297) devrinde M.Ö. 315 yılında inşa edilmiş ve kral tarafından eşi Thessaloniki'nin adı bu şehre verilmiştir. Kassander, Apollania, Chalastra, Therma, Gariskos ve Cissus bölgeler de dâhil olmak üzere toplam 26 köyden insan topluluğunu bulundukları yerden alıp Selânik'e yerleştirdi. M.Ö. 168 senesinde Makedonya Krallığı ve Roma İmparatorluğu arasında meydana gelen Pydna Savaşı, Roma'nın galibiyeti ile neticelenince Romalılar, ülkeyi dört bölgeye ayırarak federatif cumhuriyetler hâlinde teşkilâtlandırmış ve Amphipolis, Thessaloniki, Pela ve Pelagonya'yı da ülkenin merkezleri hâline getirmişlerdir.'

Selânik, Roma döneminde Balkan Yarımadası'nın transit bir limanı olması sebebiyle önemli bir role sahipti. Özellikle Romalılar tarafından bölgede kurulan Via Egnatia isimli yol, ticârî ve askerî yönden şehrin gelişmesine katkı sağlamaktaydı. Romalılar, bununla da yetinmeyip aynı zamanda Selânik'te önemli îmar faâliyetlerinde de bulundular. Yine Roma İmparatoru I. Konstantin (324-337) döneminde yaptırılan yapay liman da şehrin önemini artırmaktaydı. Theodosius (347-395) zamanında ise kentin surları inşa edildi. Bununla birlikte Selânik'te bugün Roma dönemine ait iki adet zafer kemeri de bulunmaktadır. ${ }^{2}$

Selânik sadece ekonomik bakımdan değil, aynı zamanda Hıristiyanlık tarihi açısından da önemli bir yere sahiptir. M.S. 50 yılında Havârî Paulus, ikinci seyahatinde Selânik'i de ziyaret etmiştir. Şehir 732 senesine kadar Doğu Roma Kilisesi'nin başlıca merkezlerinden biri olarak kaldı. ${ }^{3}$

518-610 yılları arasındaki zaman dilimi Bizans Devleti için Slav tehlikesinin ilk kez ortaya çıktığı devirdir. Slavların amaçları, Akdeniz kıyılarındaki çıkış noktalarına sahip olabilmektir. Hedeflerini gerçekleştirmek için seçtikleri ilk kent ise Selânik idi. Slav saldırılarının akabinde Avarların da taarruzlarına mâruz kalan ancak ele geçirilemeyen şehir bölgede Ortodoks Hıristiyanlığın kalkanı olarak varlığını muhafaza etmeye devam edecektir. VII. yüzyıla gelindiğinde Karadeniz'in kuzeyinden Balkanlara inen Bulgarlar, Selânik'e hâkim olabilmek

1 Halil Demircioğlu, Roma Tarihi Cumhuriyet Birinci Kısım Menşelerinden Akdeniz Havzasında Hâkimiyet Kurulmasına Kadar, Ankara: TTK, 1987, s. 378; William Miller, "Selonika”, The English Historical Review, Vol. 32, No. 126, 1917, s. 162; Machiel Kiel, "Selânik”, DiA, XXXVI, İstanbul: Türkiye Diyanet Vakfı Yayınları, 2009, s. 352; Kostas Theologou-Panayotis G. Michaelides, "The Role of Jews in the Late Ottoman and Early Greek Salonica", Journal of Balkan and Near Eastern Studies, Vol. 12, No: 3, 2010, s. 308.

2 Johan Baxevanis, The Port of Thessaloniki, Institute for Balkan Studies, Thessaloniki 1963, s. 3; Melek Delilbaşı, “16. Yüzyılda Via Egnatia (1380-1699)”, Sol Kol Osmanlı Egemenliğinde Via Egnatia (1380-1699), ed. Elizabeth A. Zachariadou, çev. Özden Arıkan, Ela Güntekin, Tülin Altınova, Tarih Vakfı Yurt Yayınları, İstanbul 1999, s. 7; Neslihan Ünal, İki Osmanlı Liman Kenti Izmir ve Selânik, Ankara: İmge Kitabevi, 2015, s. 153.

3 Ayhan Pala, XV. ve XVI. Yüzyıllarda Selânik Şehri, Ankara Üniversitesi Sosyal Bilimler Enstitüsü Yayımlanmamış Doktora Tezi, Ankara 1991, s. 14. 
için Bizanslılarla mücadele etmişlerdir. Şehrin tecrübe ettiği bir sonraki muhasara 904 yılında Müslüman Araplar tarafından gerçekleştirilen kuşatma ve zapt hadisesidir. 10 gün süren yağmanın ardından Araplar, 22.000 esir alarak önce Girit'e, sonra da ülkelerine döneceklerdir. Jeopolitik konumu ve hâiz olduğu önemi sebebiyle diğer devletlerin dikkatini çekmeye devam eden Selânik ilerleyen yıllarda da Bulgarlar ve Peçenekler tarafından ele geçirilmeye çalışılacak ancak onların bu teşebbüsü de başarısızlıkla neticelenecektir. 1185 senesinde, Güney İtalya'dan gelen Normanlar, 200 gemiden müteşekkil bir donanmayla kente karadan ve denizden saldırı gerçekleştirdiler. Bu hücum esnasında hem şehir yağmalanmış hem de çoğunluğu esnaf olan birçok kişi de esir alınmıştır. Selânik 1204 'te ise Lâtinler tarafından işgal edilmiş ve burada kısa süreliğine Selânik Haçlı Krallığı tesis edilmiştir. 1342 yılında Zelotların denetimine giren kent, 1349 senesinde gelindiğinde ise tekrar Bizans hükmü altına girmiştir. ${ }^{4}$ 1380 yılında ise Selânik ilk defa Osmanlı Türklerinin eline geçti. Sonraları yaşanan kayıp ve kargaşa süreçlerinde Selânik mütemadiyen el değiştirmiş, II. Murat zamanında 1430 yılının 29 Mart'ında yeniden Osmanlı topraklarına katılmıştır. ${ }^{5}$

VII. yüzyıldan itibaren Balkanlarda faâliyet gösteren devletlere kısaca bakıldığında üç önemli devlet bu dönemde öne çıkmaktadır. Bunlar: Avarlar, Slavlar ve Bizans Devleti'dir. Avarların etnik kökenine dâir yapılan tartışmalar kaynakların yetersizliği sebebiyle tarihçileri oldukça uğraştıran meselelerin başında gelmektedir. Avarlar, Doğu Roma İmparatoru I. lustinianos'un (527-565) son zamanlarından itibaren yanlarına Ogur, Sabir ve bazı Hun topluluklarını da alarak Avrupa'ya göç etmişler ve Slavlar ile ittifak tesis ederek büyük bir devlet kurmuşlardır. Tesis edilen bu devlet ortalama 250 yıl boyunca Avrupa'nın siyasî tarihine yön vermiştir. ${ }^{6}$

Slavlara bakıldığında ise; yapılan antropoloji ve dil araştırmaları Slavların Hint-Avrupa kavmine mensup olduğunu göstermektedir. Akdes Nimet Kurat, Slavlar ile ilgili şu bilgileri vermektedir: “IX.-X. yüzyıl mezarlarında bulunan iskelet kalıntıları eski Slavların ekseriyetle dolikosefal, uzun boylu, yani kuzey ırkının hususiyetlerini taşıdıklarını gösterir. Büyük göçler devrine ait bazı Slav iskeletleri üzerinde yapılan incelemeler de bu gerçekliği gösterdiği gibi VI. yüzyıl Bizans kayıtları ile IX.-X. yüzyıl Arap kaynaklarındaki bilgilere göre de Slavların sarışın bir kavim oldukları bilinmektedir. Bu suretle antropolojik hususiyetler, Slavların, German yani kuzey ırkına yakın olduklarına işaret etmektedir." Ancak zamanla yaşadıkları sahada, Fin ve Türk ırklarına

4 Pala, a.g.t., s. 15; Kiel, a.g.m., s. 352; Tayyip Gökbilgin, “Selânik”, I.A., X, MEB, İstanbul 1996, s. 338.

5 Johannis Anagnostis, Selânik'in (Thessaloniki) Son Zaptı Hakkında Bir Tarih, Sultan II. Murad Dönemine Ait Bir Bizans Kaynağı, trc. ve nşr. Melek Delilbaşı, Ankara: TTK, 1989, s. 1; Nicolae Jorga, Osmanı Imparatorluğu Tarihi, İstanbul: Yeditepe Yayınları, 2005, s. 352; Kiel, a.g.m., s. 352.

6 İbrahim Kafesoğlu, Türk Milli Kültürü, İstanbul: Boğaziçi Yayınları, 1994, s. 153; Akdes Nimet Kurat, IV.-XVIII. Yüzyıllarda Karadeniz Kuzeyindeki Türk Kavimleri ve Devletleri, Ankara: Murat Kitabevi Yayınları, 2002, s. 24; Michael Whitby, Essential Histories Rome at War AD 293-696, Osprey Publishing, 2002, s. 25; Emil Hersak, “Avarlar: Etnik Yaratılış Tarihlerine Bir Bakış”, Türkler, II, Ankara: Yeni Türkiye Yayınları, 2002, s. 644; Sevda A. Süleymanova, “Kafkasya ve Avarlar”, Türkler, II, Ankara: Yeni Türkiye Yayınları, 2002, s. 152; Yusuf Hamzaoğlu, "Slovenya'da Avar İzleri”, Türkler, II, Ankara: Yeni Türkiye Yayınları, 2002, s. 688; Osman Karatay, “Avar Hâkimiyeti ve Balkanların Slavlaşması”, Balkanlar El Kitabı, I, ed. Prof. Dr. Bilgehan Atsız Gökdağ, Prof. Dr. Osman Karatay, Ankara: Akçağ Yayınları, 2017, s. 91. 
mensup kavimlerle komşu olmaları sebebiyle Slavlar gittikçe Turanlı unsurlarla karışmaya ve ırksal özelliklerini de bu şekilde yitirmeye başlamışlardır. Yapılan araştırmalara göre, Slavların hâkimiyet tesis ettiği ilk bölge Vistül Nehri'nden başlar Pripet Havzası ve Orta Dnieper sahasını içine alır. Ancak bu bölgenin batı, kuzeydoğu ve güney sınırları tespit edilememiştir?

Bizans İmparatorluğu M.S. 330 yılından Fatih Sultan Mehmet'in 1453'te İstanbul'u fethine kadar geçen dönemde dünya tarihine yön veren en mühim devletlerden birisiydi. Bizans Devleti'nin İmpartoru I. Konstantin, M.S. 330 yılında Nova Roma (Konstantinopolis) adıyla bir şehir inşa ettirmiş ve burayı başkent ilân etmiştir. Yeni şehrin kurulması ile birlikte devlet burada yeni bir teşkilâtlanma sürecine girmiş, gelişmiş ve XIV-XV. yüzyıllar itibariyle artık bu şehir "Bizans", içinde yaşayan halk da "Bizanslı" olarak zikredilmeye başlanmıştır. ${ }^{8}$ Bilindiği gibi Bizans çok uluslu bir devlettir. Belirtmek gerekir ki, bütün bu uluslardan Hellenizm, Ortodoksluk, Hıristiyanlık ve Grek dili gibi kendi açısından oldukça önemli olan parametreler kullanılarak Bizans kültürü yaratılmıştır.

\section{5-616 Yılları Arasında Bizans-Avar-Slav İlişkileri}

II. lustinos'un (565-578) tahta çıkmasından çok kısa bir süre sonra Avarlar, imparatora Targit başkanlığında bir heyet gönderdiler. Heyetin amacı daha önce Avarlar ve Bizanslılar arasında yapılan anlaşmayı yenilemek ve yıllık vergi almaktı. Ancak Bizans İmparatoru Avarların bu isteğini reddetmiştir. İmparator II. lustinos, Avarlara yıllık verginin ancak bir hizmet karşılığında verilebileceğini ifade ederek elçileri geri göndermiştir. Bunun hemen akabinde bu kez Elbe ile Oder nehirleri arasında, daha sonra da Ren Nehri kıyılarında yerleşmiş Barbar Cermen halkı olan Lombardlar tarafından Avarlara bir ittifaklık teklif edilmiştir. Ilk başta Avarlar tarafından reddedilen bu teklif, daha sonradan Lombardların hayvanlarının 1/10'i, galip gelinirse ganimetin yarısı ve Vistül Nehri'nin etrafında hüküm sürmeye başlamış bir Cermen kavmi olan Gepidlerin işgal ettiği arazinin tamamının Avarlara verilmesi şartıyla kabul edilmiştir.9

7 Akdes Nimet Kurat, Rusya Tarihi Başlangıçtan 1917'e Kadar, Ankara: TTK, 1987, s. 3.

8 Michael Maclagan, The City of Constantinople, London 1968, s. 13; Averil Cameron, Bizanslılar, çev. Özkan Akpınar, İstanbul: Türkiye İş Bankası Kültür Yayınları, 2015, s. 7; T. E. Gregory, Bizans Tarihi, çev. E. Ermet, İstanbul: YKY, 2016, s. 74.

9 Avarlar, Bizans'a 558 yılında bir elçilik heyeti göndermişlerdir. Avarlar ve Bizans arasında gerçekleşen görüşmeler esnasında Avarlar daha önceden mücadele ettikleri kavimler hakkında Bizans'a bilgi vermişlerdir. Bizans'ın ise bu dönemde kuzeyde kendisini rahatsız eden kavimlere özellikle de Kutrigurlara karşı kullanabileceği bir müttefike intiyacı vardı. Bu görüşme sonrasında iki taraf arasında bir anlaşma yapılıp yapılmadığı şüphelidir. Kaldı ki böyle bir anlaşma yapılmış olsa dahi ertesi sene yani 559 tarihinde, tarihteki en büyük Kutrigur akını bütün Balkanları alt üst edecektir. Osman Karatay bunları Avarların harekete geçmesinden önceki son büyük Kutrigur akını olduğunu ifade eder. Nitekim Avarlar bütün bu olaylardan sonra 562 tarihinde Bizans'a yeniden bir elçilik heyeti gönderecekler, kendi vazifelerini yerine getirdiklerini ve bunun karşılı̆ında artık Bizans'tan para değil yerleşecek toprak isteyeceklerdir. İmparator lustinianos (527-565) ise o dönemde Akdeniz fetihleri ile uğraştığı için ve aynı zamanda eski Roma'yı yeniden kurmaya çalıştığı için Bizans'ın düşmanı olan Gepidlerin yaşadığı Sava ve Drova nehirleri arasındaki bölgeyi Avarlara vermiştir. Aynı zamanda lustinos bir taraftan savunma önlemleri alırken diğer taraftan da bugünkü Romanya arazisinde yaşayan Ant Slavlarını kışkırtmaya başladı. Avar Kağanı Bayan, Franklar ile savaşa girmesi yüzünden bu hakarete geçici olarak katlanmıştır. Karatay, "Avar Hâkimiyeti ve Balkanların Slavlaşması”, s. 93; Mustafa Gülem, Doğu Roma (Bizans) Imparatorluğu'nun Dış Politikası (Erken Bizans Dönemi 330-718), Cumhuriyet Üniversitesi Sosyal Bilimler Enstitüsü Yayımlanmamış Yüksek Lisans Tezi, Sivas 2015, s. 44 
Gepidlerin ortadan kalkmasından sonra bu millete ait olan Sirmium, Bizanslıların eline geçmiştir. Avarların Hakanı Bayan Han (562-602) ise bu şehri Bizanslıların elinden almak istiyordu. Nitekim bu amaçla Sirmium'a ânî bir saldırı düzenlemiş ancak başarılı olamamıştır. Ancak bu başarısızlığın ardından boş durmayan Bayan Han, kente elçiler göndererek şehrin kumandanı Bonus'tan bazı isteklerde bulunmuştur. Ancak Bizans Devleti ve Avarlar arasında bir anlaşma sağlanamamıştır. Bunun üzerine Bayan Han 10.000 Kutrigur ve Utigur'a Sava Nehri'ni geçirmiş, bunlar öncelikle Dalmaçya'ya girmiş ve etrafı yağmalayarak birçok yeri istilâ etmişlerdir. Yaşananların hemen arkasından Avarlar, Bizans ile bir muharebeye girişmişlerdir. Bizans İmparatoru, Avarlar karşısında tutunamayacağını anlayınca, onlarla bir anlaşma imzalamış ve Avarlara yıllık vergi ödemeyi kabul etmiştir. ${ }^{10}$

578'de Bayan Han, Slavlardan yıllık vergi talep etmiş ancak Slavlar bunu kabul etmedikleri gibi Avarlar tarafından gönderilen elçileri de öldürmüşlerdir. Aynı dönemde Bizans Devleti'nde durum pek iç açıcı değildir. Sâsânî Kralı I. Hüsrev (531-579), Anadolu ve Suriye'yi tahrip ederken, Lombardlar ise İtalya'yı işgal etmişlerdir. I. Tiberios Konstantinos (578-582), Hüsrev'i yenmeyi başarmış ancak bu kez de Slavlar Balkan topraklarında büyük bir tahribatta bulunmuşlardır. Bizans İmparatoru, bu zor durumda Slavlardan intikam almak için Avarlardan yardım istemiştir. Bayan Han, zaten daha önceden öldürülen elçilerinin intikamını Slavlardan almak istediği için bu teklifi kabul etmiş ve 60.000 kişilik bir orduyla Panonya'dan Llyricum'a geçmiştir. Oradan da Tuna Nehri'ni geçerek Slavlara hücum etmiştir. Bu mücadelede, Slavlar, Avarlar karşısında tutunamayarak firar etmek zorunda kalmışlardır. Avarlar, Slavlar ile yaptıkları bu mücadele neticesinde birçok ganimet elde etmelerine rağmen daha sonraki süreçte Sirmium meselesi yüzünden Avarlar ile Bizanslılar tekrar karşı karşıya gelmişlerdir. Bayan Han, en nihayetinde Avarlar açısından jeostratejik öneme hâiz, Bizans üzerine yapılacak akınlarda üs olarak kullanabilecekleri Sirmium'u 582 yılında ele geçirmiştir. Sirmium'un Avarların hükmü altına girmesiyle birlikte Orta Tuna bölgesi, Avarlar ve Bizans arasında hudut olmuş ve Balkanların ele geçirilmesi açısından da Avarlara bir kapı açılmıştır. ${ }^{11}$

Bizans İmparatoru Mavrikios (582-602) imparator olduktan kısa bir süre sonra Bayan Han, Bizans'a elçiler göndermiş ve onlarla bir anlaşma yapmıştır. İki taraf arasında yapılan ve iki yıl süreli bu anlaşma gereğince Bizans İmparatorluğu, Avarlara 80.000 altın haraç ödeyecektir. Avarlar, bu anlaşmadan bir müddet sonra Bizans'a yeniden elçiler göndererek 80.000 altın olan haracın 100.000 altına çıkartılmasını isteyecekler lâkin bu teklif Bizans tarafından kabul edilmeyecektir. Bu durum üzerine Avarlar 584 yılında Singidunum'a (Belgrad) hücum edip

10 Radi Dikici, Bizans Imparatorluğu Tarihi (Şu Bizim Bizans-Byzantium 330-1453), İstanbul: Remzi Kitabevi, 2013 , s. 148; J. Julius Norwich, Bizans (Erken Dönem M.S. 323-802), I, çev. Hamide Koyukan, İstanbul: Kavalcı Yayınları, 2013, s. 219-220; Gülem, a.g.t., s. 44, Hersak, a.g.m., s. 645; Hamzaoğlu, a.g.m., s. 688; Ali Ahmetbeyoğlu, "Hun Akınları Çağında Balkanlar", Balkanlar El Kitabı, I, ed. Prof. Dr. Bilgehan Atsız Gökdağ, Prof. Dr. Osman Karatay, Ankara: Akçağ Yayınları, 2017, s. 88.

11 Georg Ostrogorsky, Bizans Devleti Tarihi, çev. Fikret Işıltan, Ankara: TTK, 2011, s. 75; Umay Türkeş Günay, Türklerin Tarihi, Ankara: Akçağ Yayınları, 2007, s. 115; Karatay, a.g.m., s. 94. 
şehri ele geçirmişler ve gerçekleştirilen bu fetihle Balkan yolu Avarlara tamamen açılmıştır. Değişen şartlar uyarınca Avarlar, Slavlar ile de ittifak kurmuşlardır. Bu süreçte Yunanistan'ın güney uçlarına kadar ulaşan Avar-Slav orduları Selânik'i iki kez muhasara etmişlerdir. Aynı dönemde ise Bizans Devleti, Sâsânî cephesi ile meşguldür. Bundan dolayı Avar-Slav orduları ciddi bir direnişle karşılaşmadan Balkan topraklarında ilerlemişlerdir. Yaşanan gelişmeler üzerine Orta Balkanlardaki ahâli evlerini terk ederek sahil bölgelerine çekilmek zorunda kalınca Avarlar ve Slâvlar daha önceki akınların aksine bu kez geri dönmeyerek 580'lerden itibaren hâlî olmuş topraklara yerleşmeye başlamışlardır. Bizans Devleti ise ancak Sâsânî ile arasındaki savaşın nihayete ermesinden sonra Avar-Slav birlikleriyle olan mücadelesine devam edebilecektir. Ancak müttefikler Bizans'ın karşısına doğrudan çıkmayarak ara ara düzenledikleri hücumlarla ezeli düşmanlarını mütemadiyen zâyiata uğratacaklardır. ${ }^{12}$

Phokas dönemi (602-610) ile birlikte Bizans, kuzeyde hâkimiyetini tamamen yitirmiştir. Bu devirde Dalmaçya, Arnavutluk, Yunanistan, Güney Makedonya ve Trakya sahillerinin bazı kısımları hâriç Balkanların tamamına Slavlar yerleşecektir. Phokas, tahta çıkar çıkmaz, Avarlara barış teklif etmek zorunda kalmıştır. Nitekim Bizans bu dönemde hem Sâsânî ile yeni bir savaşa girmek üzeredir hem de Avarlar Bizans'tan yıllık vergi istemişlerdir. 590'larda Balkanlarda başlayan mücadelelerde, Bizans siyasî istikrarsızlıklar sebebiyle başarılı olamayınca Slav-Avar toplulukları bölgeye rahatlıkla yerleşmişlerdir. ${ }^{13}$

610 yılında Herakleios, Kartaca'dan İstanbul'a gelmiş ve Phokas'ı tahttan indirerek, kendisi imparator olmuştur (610-641). Bu dönemde Bizans'ın Sâsânî ile mücadelesi devam etmektedir. Bundan dolayı da Slavlar ve Avarlar da Balkanlarda istedikleri gibi hareket etmektedirler. Özellikle Bizans Devleti'ndeki taht değişikliğini de fırsat bilen Slav-Avar birlikleri, Balkanlardan güneye inerek Teselya, Epir, Trakya ve Selânik'e saldırmışlardır. Böylece Teselya üzerinden Avar-Slav dalgası Orta Yunanistan ve Pelepones'e kadar ulaşmıştır. 614 yılında ise Salona bölgesi tahrip edilmiş, böylece Balkan Yarımadası'nın batı kısmının kontrolü de Bizans'ın elinden çıkmıştır. Bunun yanı sıra Slavlar Girit'e çıkarma yapmışlar ve Bizans'ın en önemli üsleri olan Viminacium, Niş, Sofya gibi şehirler de tahrip edilmiştir. İstanbul ise bu kuvvetli akınlardan güçlü surları sayesinde kurtulmuştur. Bu durum karşısında Bizans İmparatoru Herakleios, Avarlara elçi göndererek, barış istemek mecburiyetinde kalmıştır. Avarlar, Bizans elçilerini oldukça sıcak karşılamışlar hatta Bizanslıların dostları olduklarını ifade etmişlerdir. Avar Kağanı II. Behan (602-617), Bizans İmparatoru'nu ziyaret etmek istediğini bildirmiş ve Bizans İmparatoru'na Muğla sınırları içinde bulunan antik kent Heraklea'da görüşmeyi teklif etmiştir. İmparatoru ele geçirmek niyetiyle böyle bir talepte bulunan Avarlar plânlarını gerçekleştirme hususunda başarılı olamamışlardır. Avar kuvvetlerinin birtakım hareketleri köylülerin dikkatini

12 Norwich, a.g.e., s. 226; Fatma Çapan, Balkanlarda Bizans-Türk Ilişkileri, Fırat Üniversitesi Sosyal Bilimler Enstitüsü Yayınlanmamış Doktora Tezi, Elazığ 2013, s. 109; Karatay, a.g.m., s. 94.

13 Ostrogorsky, a.g.e., s. 77; Norwich, a.g.e., s. 226; Karatay, a.g.m., s. 95. 
çekmiş ve bu sebepten Bizans İmparatoru esir olmaktan kurtulmuştur. ${ }^{14}$ Balkan coğrafyasında Bizans, Avar, Slav üçgeninde yaşananlar hakkında genel itibariyle verilen bu bilgilerden sonra çalışmanın asıl konusunu teşkil eden 617/618 Selânik kuşatmasıyla ilgili verdiği bilgilerden ötürü ayrı bir öneme sahip Aziz Demetrios hakkında bilgi vermek yerinde olacaktır.

Gerek ticarî gerek stratejik özelliklerinden dolayı sahip olduğu ehemmiyetinden ötürü Avar-Slav birlikleri Selânik üzerine çeşitli dönemlerde seferler düzenlemişlerdir. Bu seferlerden bir tanesi de Aziz Demetrios Mucizeleri'nde de yer bulan 617/618 Selânik muhasarasıdır.

\section{Aziz Demetrios}

Demetrios, hem Ortodoks hem de Katolik toplumunda kabul görmüş bir asker ve aziz olarak karşımıza çıkmaktadır. Diğer yandan Aziz Demetrios'un Selânikli zengin bir aileye mensup olduğu bilinmektedir. ${ }^{15}$

Özellikle Hıristiyanlığa karşı baskıların şiddetlendiği bir dönemde, Roma ordusunda görevli olmasına rağmen Aziz Demetrios'un IV. asır başlarında Hıristiyanlığı Selânik'te yaymakla hemhâl olduğu görülmektedir. Bundan dolayı da İmparator Maximianus'un (286-305) gazabına uğrayacak ve öldürülecektir. Aziz Demetrios'un tam olarak nerede hayatını kaybettiği ise bilinmemektedir. ${ }^{16}$

Bazı araştırmacılara göre, Aziz Demetrios Selânik’te öldürülmüş ve buradaki Hıristiyanlar tarafından da gizlice defnedilmiştir. ${ }^{17}$ Ancak başka bir grup bu görüşü kabul etmemektedir. Zîra ilgili araştırmacılar Aziz Demetrios'un Selânik’te öldürülmediği fikrini savunurken, Martyrologium Hieronymianum isimli Yunanca eseri temel alarak hazırlanan Süryânî Breviarium'daki bilgileri göz önünde tutmuşlardır. Nitekim söz konusu eserde Selânik'te hayatını kaybeden Demetrios'tan hiç bahsedilmemektedir. ${ }^{18}$

Aziz Demetrios'un ölümünden sonra Başpiskopos loannes tarafından kaleme alınan ve bu makalede ana kaynak olarak kullanılan Aziz Demetrios'un Mucizeleri isimli eser, hem Aziz Demetrios hem de ölümünden sonra onun mucizelerinin Selânik'i koruması hakkında bilgiler vermektedir. Tanrıya şükran ilâhisi olarak sunulan bu yapıt, İmparator Herakleios'un saltanatının ilk 10 yılında Selânik Başpiskoposu loannes tarafından te'lif edilen didaktik bir kaynak niteliğindedir. Aziz Demetrios'un Mucizeleri kent ve sakinlerinin yararına yapılan 15 mucizeyi içermektedir. Bununla birlikte eserin yazılış amacı, Selâniklilere, Demetrios'un onların yurttaşları ve kendi azizleri olduğunu, her zaman onlarla birlikte bulunduğunu ve şehri korudu-

14 Ostrogorsky, a.g.e., s. 88-89; Norwich, a.g.e., s. 229; Celaleddin Basık, Hiç Bizans Olmadı Romulus'tan Fatih'e Roma Devleti, I, İstanbul: Türkmen Kitabevi, 2013, s. 208; Karatay, a.g.m., s. 95.

15 İlkgül Kaya Zenbilli, “Aziz Demetrios: Selânik’in Koruyucu Azizi, Yaşam Öyküsü ve Mucizeleriyle Illişkili Belgeler, Kültü ve Tasvirleri”, Ortaçağ Araştırmaları Dergisi, Bizans Dosyası, C. 3, S. 2, 2020, s. 362.

16 M. Vickers, "Sirmium or Thessaloniki? A Critical Examination of The St. Demetrius Legend", Byzantinische Zeitschrift 67 (2), 1974, s. 341; P. Magdalino, “Saint Demetrios and Leo VI”, Byzantinoslavica LI (2), 1990, s. 198.

17 Zenbilli, a.g.m., s. 362.

18 D. Woods, “Thessalonica's Patron: Saint Demetrius or Emeterius?”, The Harvard Theological Review 93/3, 2000, s. 221-222. 
ğunu göstermektir. Bundan dolayı eserde, Aziz Demetrios, Selânik için çalışan, vebâ, kıtlık ve iç savaş gibi olağandışı hâllerde ve düşman unsurlarına karşı yürütülen harp durumunda tüm vatandaşları adına müdâhalede bulunan bir kişi olarak gösterilmektedir. Başpiskopos Ioannes'in bazen anlatılan olaylara tanık olarak çağırdığı dinleyicilere (oi ảkoúovtعc) hitap etmesi, bu mucizelerin vaaz şeklinde aktarılmasının amaçlandığını düşündürmektedir. ${ }^{19}$ Ancak eserde, Florin Curta'nın da belirttiği üzere, hadiseler anlatılırken kronolojiye dikkat edilmemiştir. Bu sebeple çalışmaya temkinli yaklaşılması gerektiği hakikatı ortaya çıkmaktadır. ${ }^{20}$

\section{Aziz Demetrios'un Mucizeleri'nde 617/618 Selânik Kuşatması}

Aziz Demetrios'un Mucizeleri isimli eserin giriş kısmı, Başpiskopos loannes'e bir övgüyle başlar ve onun hakkında şunları söyler: “...bu defa ise konuşmanın merkezi daha önceden ismi geçtiği üzere loannes, o ki aynı zamanda ölümünden sonra bile hâlâ buradaymış gibi yardımımıza koşar ve gerek hemşehrisini gerek arkadaşı olan şehit Demetrios ile birlikte bizim için Tanrı'nın merhametini diler. Isste bu yüzden onun hatıralarını ve tembihlerini sonsuza kadar muhafaza etmemiz uygun düşer. "21

Aziz Demetrios'un Mucizeleri'nde, 614-616 yılları arasında Slav saldırılarının Avar taarruzları kadar yoğunlaştığı Selânik şehri muhasaralarından söz edilmektedir. Ancak Selânik'i kendi başlarına ele geçiremeyen Slavlar, askerî yardım talep etmek için Avarlara hediyeler ile beraber bir de elçilik heyeti göndermiştir. Slavların bu teklifi Avarlar tarafından kabul edilmiştir.22

“...daha önce zikredildiği üzere Chatzon'un [emri altındaki] Sklavenler (Slavlar), Igerçekleştirdikleri] saldırıların ve Aziz Demetrios'un onları kırıp geçirmesinin akabinde yalnızca utanç duymakla kalmadılar aynı zamanda ele geçirmiş oldukları tutsakların sığınma aramak amacıyla Selânik'e gelmeleri ve dahası Slavların ele geçirdikleri ganimetin bir kısmını da kendileri ile birlikte götürmeleri sebebiyle de büyük zarar gördüler. Bu sebeple onlar [Slavlar] kıymetli hediyeleri topladılar ve kendilerine yardım etmesi koşuluyla Selânik kuşatmasından elde edilecek büyük miktarda ganimet ve para sözünü de vererek Avar Kağanı'na gönderdiler. Onlar bu kuşatmanın kolay olacağı garantisini verdiler. Tüm şehirler ve civar bölgeler ellerinde olup, insansızlaştırılmıştı (nüfusu azaltılmış); yalnızca Selânik onların ortasında soyutlanmış bir şekilde direndi ve Tuna civarındaki ülkelerden Panonya Daçya, Dardanya ve iskân edilmiş başka yerlerden gelen tüm mültecileri kabul etti."23

19 Florin Curta, The Making of the Slavs History and Archaeology of the Lower Danube Region c. 500-700, Cambridge University Press, Cambridge 2001, s. 52-53.

20 Curta, a.g.e., s. 53-54.

21 Paul Lemerle, Les Plus Anciens Recueils Des Miracles De Saint Dèmètrius Et La Pènètration Des Slaves Dans Les Balkans, I, Du Centre De La Recherche Scientifique, Paris 1979, s. 180.

22 Georgios Kardaras, Byzantium and the Avars, 6th-9th Century AD Political, Diplomatic and Cultural Relations, Leiden-Boston: Brill 2018, s. 77.

23 Lemerle, a.g.e., s. 181. 
Değinildiği üzere Bizans Devleti'nde VI. yüzyılın sonlarından itibaren, münferit Slav yerleşmeleri vuku bulmuştu. VII. yüzyılın ilk yıllarından itibaren ise İmparator Mavrikios'un Tuna Seferi'nin akâmete uğramasından sonra Slavlar daha geniş bölgelere sahip olmaya başlamışlardır. Avarlar ise bütün Balkan Yarımadası'na, batıda Adriyatik kıyılarına, güneyde ve doğuda Ege sahillerine kadar uzanmaktaydılar. Nitekim ağır istilâ ve tahribattan sonra tekrar Tuna gerisine çekiliyorlardı. Fakat Slavlar, Balkan Yarımadası'na kuvvetle yerleşiyor ve bölgeyi işgalleri altına alıyorlardı. Bu durum en nihayetinde Balkanlardaki Bizans hâkimiyetinin yıkılmasına sebebiyet verdi. Bütün Tuna eyaletleri ve Makedonya, Slavlar tarafından ele geçirilmişti ve Trakya, İstanbul önlerine kadar tahrip edilmişti. Özellikle Slav-Avar orduları tarafından Selânik üzerine yapılan saldırılar çok şiddetliydi. ${ }^{24}$

Çevresindeki hemen bütün yerleşim merkezleri ele geçirilmesine rağmen Selânik saldırılara direnmekteydi. Bizans Devleti'nin Balkanlardaki en önemli üslerinden olan Belgrad, Niş ve Sofya gibi şehirler harap edilmişti. Bunun bir sonucu olarak Bizans'ın elinde Selânik, Zara, Trogir, İşkodra ve Arnavutluk sınırları içerisinde bulunan Lyes (Leş) gibi birkaç kent kalmıştı.

Diğer taraftan Slavlar tarafından yapılan anlaşma teklifi Avar Kağanı tarafından kabul edildi. Avar Kağanı iki yıllık bir hazırlıktan sonra Slav ve Bulgar toplulukları ile diğer bağı kabilelerden müteşekkil bir orduyla harekete geçti ve 617/618'de Selânik'in dış mahallelerine ulaştı. ${ }^{25}$

Bu kuşatma, Aziz Demetrios'un Mucizeleri'nde şu şekilde ifade edilir: “...kağan bu teklifi memnuniyetle kabul ederek, toprakları üzerinde yaşayan tüm barbar kabileleri, Slavlar, Bulgarlar ve diğerleri ile birlikte harekete geçirdi ve iki yılın sonunda Selânik'e karşı sefere koyuldu. Önden gönderdiği seçkin süvariler, beklenmedik bir anda şehrimize saldırı gerçekleştirerek kent surlarının dışında buldukları kişileri öldürdüler ya da esir ettiler. Daha sonra kuşatma makineleri ve ordunun tamamı ile gelen kağanı beklediler. Bu plân doğrultusunda barbarlar silâhlarını kuşandılar ve zırhlı süvariler aniden dört bir yanda görünerek hasat için tarlalarında bulunan Selâniklilere saldırıp onları öldürdüler ya da esir ettiler. Ayrıca buldukları tüm sığırları ve ziraî makineleri de ele geçirdiler."26

Bu durum Selânik halkında büyük büyük bir endişeye sebebiyet vermiştir. Niş ve Sardika'dan (Sofya) gelenlerin Slavlar ve Avarlar hakkında vermiş oldukları bilgiler de halkın endişelenmekte hiç de haksız olmadıklarını göstermektedir.

24 Ostrogorsky, a.g.e., s. 87.

25 Kardaras, a.g.e., s. 78.

26 Lemerle, a. g. e., s. 181. 
“...ve [barbarların] şehir muhasarasını tecrübe etmiş ${ }^{27}$ olan Nis [Niş] ve Sardika'dan [Sofya] gelenler gözyaşlarıly konuştular: 'Biz oradan kaçtık ve buraya geldik ki seninle beraber yok olalım; (çünkü onların mancınıklarından çıkan) taşların bir darbesi surları yıkabilir'." Kuşatma âletlerinin hâkim olduğu kuvveti göstermesi bakımından bu ifadeler dikkate değerdir.

Aziz Demetrios'un Mucizelerinde Selânik halkının bu kuşatmaya karşı hazırlık yaptığı zikredilir. Ancak aynı zamanda böylesi kalabalık demir-zırhlı Slav-Avar müşterek ordusunun getirdiği kuşatma âletlerinden de bahsedilerek Selâniklilerin kapıldığı dehşet tasvir edilmeye çalışılmıştır. Nitekim iç surların boyunu aşan petroboller, ${ }^{28}$ tahtadan yapılmış deriyle kaplı kaplumbağalar, ${ }^{29}$ hareket ettirilebilir merdivenler ve ateş fırlatan makineler metinde geçen kuşatma âletlerindendir.

Selânik halkı şehri bu defa koruyamayacaklarına kāni olmuşlardı. Ancak Piskopos loannes, şehrin muhasara altında bulunmasından dolayı kaygı ve üzüntü içerisinde bulunan ahâliyi Slavlara ve Avarlara karşı mukavemet etmeleri için cesaretlendirmekteydi. Piskopos loannes aynı zamanda Selânik'in, Aziz Demetrios'un koruması altında olduğunu anlatarak halkın umudunu artırmaya gayret ediyor ve bu arada gemiler vasıtasıyla da kente zahîre ikmâli sağlanmaya çalışılıyordu. Bundan bir müddet sonra Avar Kağanı ana orduyla birlikte bizzat Selânik önlerine geldi. Şehrin müdâfaası için gerekli hazırlıklar ise devam ediyor ve halk Tanrı'dan yardım istiyordu. Selânik güçlü surlara sâhipti ve daha önceki kuşatmalara göğüs germişti. Ancak şehir halkı bu defa kurtulamayacaklarını düşünmekteydiler. Bununla birlikte Bizans İmparatoru şehrin durumu hakkında bilgi aldıktan sonra Harias [Xapíaç] adındaki kumandanın emrine verdiği orduyu şehri muhafaza etmesi için bölgeye gönderdi. Diğer taraftan Avarlar ve Slavlar da kent surlarının ötesinde taarruzlarını sürdürmekteydiler. Ancak kuşatmanın uzaması askerlerin yorgunluğunu artırmakta ve de tahammüllerini azaltmaktaydı. Bu sebeple Avar Kağanı hediyeler almak koşuluyla muhasarayı sona erdireceğini şehre iletmiş ancak Avarların bu talebine Selânikliler menfî bir yanıt vermişlerdir. Bunun üzerine Avar Kağanı şehrin etrafındaki tüm ev ve kiliselerin yakıımasını emretti. Öte yandan Avarlar bölgeye yeni takviye birlikler getirmeyi düşünmekteydiler. Lâkin daha sonra Avar Kağanı aldığı hediyeler karşıı̆ında elindeki esirleri serbest bırakarak muhasarasını kaldırdı. ${ }^{30}$

27 Niş ve Sardika, Dardanya Eyaleti'nin şehirleriydi. Eserin müellifine göre Dardanya vilâyeti, Avar Kağanı'nın Selânik muhasarasından önce harap edilmişti. Son tahlilde Niş ve Sardika gibi kentler 615 senesinden önce vîran hâlde idiler.

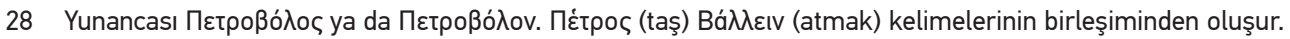
"Taş-atan, taş-fırlatan" sıfatından türeyen bu isim zamanla savaş makinesinin adı hâline gelmiştir. Ayrıntılı bilgi için bkz. Arthur de Graauw, Ancient Coastal Settlements Port and Harbours, Vol. III / Ancient Port Structures, Grenoble 2020, s. 267.

29 Bu hareket edilebilir büyük siper, altında bulunanları koruduğu için kaplumbağa kabuğuna benzetilerek kaplumbağa adı verilmiştir. Buna Batı dillerinde tortoise ya da testudo da denilmektedir. Ayrıntılı bilgi için bkz. Philip Rance, "The Fulcum the Late Roman and Byzantine Testudo: the Germanization of Roman Infantry Tactics?", Greek, Roman and Byzantine Studies, 44 (2004), s. 265-326.

30 "Miracula St. Demetrii II", Vizantijski Izvoriza Naroda Jugoslavije, Sırpça trc. Franjo Barišić, I, Belgrad 1955, s. 196. 
Aziz Demetrios Mucizesi'nde, kuşatma başladıktan sonra üç mucizenin gerçekleştiğinden bahsedilir. Birinci mucize, yoğun petrebol atışı esnasında, Selânikli bir taş hizmetlisi ilâhî bir ilham ile bir taşın üzerine Aziz Demetrios yazar ve "Tanrı ve Aziz Demetrios adına" diye haykırarak taşı fırlatır. Bu taş kendi istikametinde iken barbarlar tarafından atılmış son derece büyük bir taşa çarpar ve o taş da geri dönerek, üzeri yazılı taşla birlikte bir düşman petrebolü'nün üst açıklığından, iç kısma düşer. Orada bulunan hizmetliler ve kişiler de üzerlerine düşen bu taş sebebiyle hayatlarını kaybederler. İkinci mucizede, muhasaranın devam ettiği günlerden birinde öylesine büyük bir deprem olmuştur ki tüm şehir ahâlisi tek bir sadâ ile Kyrie eleison ${ }^{31}$ diye bağırmaya başladılar. Surların yıkıldığını gören düşmanlar da şehri ele geçirmek için hücuma geçtiler. Ancak düşman surlara yaklaştığında su duvarlarını eskisi gibi sapasağlam ayakta buldular. Bir diğer ve son mucizede ise, barbarların kar tanecikleri gibi yoğun bir şekilde fırlattıkları oklardan bazılarının arka tarafındaki tüylü kısımları surlara saplı ve demir ucu ise düşmana doğru bakar görünmekteydiler. ${ }^{32}$

Avar Kağanı yaşanan bütün bu olaylar neticesinde 33 gün süren kuşatmayı kaldırmak zorunda kalmıştır. ${ }^{33}$ Bundan sonraki durum Aziz Demetrios'da şu şekilde anlatılmaktadır: “Barış tesis edildikten sonra, barbarlar [ellerinde bulunan] esirleri düşük meblağlara satmak ve çeşitli ürünler için pazarlık etmek amacıyla korkusuz bir şekilde surlara yanaştılar. Onlar Tanrı tarafından şehre bahşedilen kurtuluşu, deprem esnasında surlarda [meydana gelen] mucizeyi, silâh ve savaş makinelerini, [ki] daha önceki birkaç hâdisede [bu silâhların] tesirine şâhit olmuşken, kullanışsız hâle getiren ve kendilerine beliren azizlerin görünümlerini açıkça kabul ettiler. Şehrimizin tüm tehlikelerden ve barbarlardan Aziz Demetrios'un şefâati vesilesiyle kurtulduğunu da, bunu bizzat tecrübe etmemiz sebebiyle burada söylemek gerekir." ${ }^{\text {34 }}$

Hem Selânik hem de Slav-Avar ittifakı açısından enteresan bilgilerin verildiği bu kuşatma esnasında yaşananlar her iki cephe içinde yorucu ve yıpratıcı olmuş görünmektedir. Bu kuşatma sonrasında yaşananları değerlendirmemiz gerekirse öncelikle şunu belirtmekte fayda bulunmaktadır; Aziz Demetrios, senatöryel bir ailenin çocuğu olarak 270 yılında dünyaya gelmiştir. Daha sonraki süreçte Sirmium'dan Selânik'e gelen Aziz Demetrios, bu tarihten itibaren Selânik'in koruyucu azizi olarak kabul edilmiştir. Selânik'in muhafızı olarak anılan, Selânik'e geldikten sonra Hıristiyanlık dinini kabul eden Demetrios, Selânikli vatandaşlara puta tapmamaları, bunun yerine kalplerini Hz. İsa'ya açmaları konusunda telkinlerde bulunmuştur.

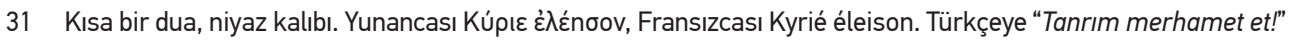
ya da "Şefâat yâ Rabb!" şeklinde çevrilebilir.

32 Lemerle, a.g.e., s. 182.

33 Eserin müellifine göre (1340 № 172) bu onların yaşadıkları en kötü muhasaraydı. Muhtemelen sözü geçen bu bilginin doğru olması gerekir. Zîra daha önceden de belirtildiği gibi Avarlar, Selanik'i kuşatabilmek için iki yıl boyunca hazırlık yapmışlardı. Bununla birlikte muhasara ise tam bir aydan fazla sürmüştü. Ancak müellifin uzun bir süre boyunca devam eden kuşatma hakkındaki bilgileri yetersizdir. Zaten müellif de (1336 № 168) bunu dolaylı olarak kabul etmiştir. Yedi günlük kuşatmanın açıklaması için bkz. Mir., I, 13-15. Bununla birlikte daha fazla bilgi ve ayrıntı için bkz. Mir., l, 13 № 107, 110,111 ile Mir., 11 2, № 168, 170-72.

34 Lemerle, a.g.e., s. 184. (Bu muhasara hakkında bkz. 180-184) 
Roma Imparatoru Maximianus tarafından zindana atılan Demetrios, oradan da vaaz vermeye devam etmiştir. Bundan dolayı da Maximianus tarafından öldürülmüştür. Ancak ölümünden sonra bile Selânik'in koruyucusu olarak anılmaya devam etmiş̧ir. Nitekim Aziz Demetrios'un Mucizeleri isimli eserin giriş kısmında onun koruyucu rolüne bilhassa vurgu yapılmış ve Demetrios'un ölümünden sonra dahi Selânikliler için Tanrı'nın merhametini dilediğinden söz edilmiştir. Yine Chatron'un (Chatzon) emri altındaki Slavların, Balkanlardaki saldırısının Aziz Demetrios tarafından durdurulduğu, Slavların ellerindeki tutsakların, ele geçirmiş oldukları ganimetler ile birlikte Selânik'e gelmeleri sebebiyle onların çok büyük bir zarara uğratıldığı da kaynak eserde zikredilmektedir. Balkanlarda tek başlarına mücadele edemeyeceklerini anlayan Slavlar, bu hâdise sonrasında Avarlardan yardım isteyeceklerdir.

Avar-Slav birliklerinin en önemli hedefi Balkanlarda tutunabilmek idi. Bu hedeflerinin büyük ölçüde gerçekleşmesiyle birlikte Balkanlardaki birçok şehir Avar-Slav kuvvetleri tarafından ele geçirilmiştir. Ancak bu başarıı kazanımlardan bir tek Selânik şehri istisna olacaktır.

İstanbul'dan sonra Bizans'ın en önemli ikinci şehri olan Selânik kenti, hem transit liman olma özelliği dolayısıyla ekonomik ve askerî yönden hem de Havârî Paulus'un bu şehri ziyareti münasebetiyle Hıristiyanlık tarihi açısından oldukça önemlidir. Slav-Avar birlikleri özellikle Akdeniz kıyısına çıkmak için kilit olarak gördükleri Selânik üzerine çeşitli dönemlerde birçok sefer düzenleyecekler ancak bu seferlerde herhangi bir başarı sağlayamayacaklardı. Gerçekleştirilen bu seferlerden bir tanesi de 617/618 yilında yapılan hücumdur. Slavlar ve Avarlar var güçleriyle saldırmalarına rağmen başarıı olamamışlar ve Selânik ele geçirilememiştir. Avar ve Slav birliklerinin bir diğer yandan Balkanlarda bu kadar rahat faaliyette bulunmalarının en temel sebebi bu dönemde Bizans'ın, Sâsânî ile mücadele etmesinden dolayı yaşamış olduğu siyâsî istikrarsızlıktır. Slav-Avar birliklerinin Selânik'i muhasara etmeleri halkta endişeye sebebiyet vermiştir. Kaynağa göre, özellikle Niş ve Sardika'dan gelerek, Selânik'e sığınan insanların Slav-Avar birlikleri hakkında vermiş oldukları bilgiler onların korkularını daha da artırmıştır. Slav-Avar müşterek ordusunun kullanmış oldukları savaş âletleri Selâniklilerin dehşete kapılmalarına sebebiyet vermiştir. İşte tam da bu noktada yapıtın da ismi olan Aziz Demetrios'un Mucizeleri gerçekleşmiş ve Selânik, Slav-Avar saldırısından vuku bulduğu ifade edilen mucizeler vasıtasıyla kurtulmuştur.

Her ne kadar Slav-Avar birlikleri Selânik'i ele geçirememiş olsalar dahi Slavların, Balkanlara yerleşmesi Avarlar vesilesiyle bu dönemde gerçekleşmiştir. Avarlar düzenlemiş oldukları seferler sonrasında geri çekilirken Slavlar bu bölgeye yerleşmişlerdir. Ifade etmek gerekir ki, Avarların desteği olmasaydı Slavların bu bölge üzerinde hâkimiyet kurmaları mümkün olmayabilirdi. Netice olarak, bugün Balkanlardaki Slav varlı̆ııın temellerinin Avarlar eliyle o dönemde gerçekleştiği ifade edilebilir. 
Hakem Değerlendirmesi: Dış bağımsız.

Çıkar Çatışması: Yazar çıkar çatışması bildirmemiştir.

Finansal Destek: Yazar bu çalışma için finansal destek almadığını beyan etmiştir.

Peer-review: Externally peer-reviewed.

Conflict of Interest: The author has no conflict of interest to declare.

Grant Support: The author declared that this study has received no financial support.

\section{Bibliyografya}

“Miracula St. Demetrii II”, Vizantijski Izvori za Naroda Jugoslavije, Sırpça trc. Franjo Barišić, I, Belgrad 1955. Ahmetbeyoğlu, Ali, “Hun Akınları Çağında Balkanlar”, Balkanlar El Kitabı, I, ed. Prof. Dr. Bilgehan Atsız Gökdağ, Prof. Dr. Osman Karatay, Akçağ Yayınları, Ankara 2017, s. 75-90.

Anagnostis, Johannis, Selânik'in (Thessaloniki) Son Zaptı Hakkında Bir Tarih, Sultan II. Murad Dönemine Ait Bir Bizans Kaynağı, trc. ve nşr. Melek Delilbaşı, Ankara: TTK, 1989.

Basık, Celaleddin, Hiç Bizans Olmadı Romulus'tan Fatih'e Roma Devleti, I, İstanbul: Türkmen Kitabevi, 2013. Baxevanis, Johan, The Port of Thessaloniki, Institute for Balkan Studies, Thessaloniki 1963.

Cameron, Averil, Bizanslılar, çev. Özkan Akpınar, İstanbul: Türkiye İş Bankası Kültür Yayınları, 2015.

Curta, Florin, The Making of the Slavs History and Archaeology of the Lower Danube Region c. 500-700, Cambridge University Press, Cambridge 2001.

Çapan, Fatma, Balkanlarda Bizans-Türk Ilişkileri, Fırat Üniversitesi Sosyal Bilimler Enstitüsü Yayınlanmamış Doktora Tezi, Elazığ 2013.

Delilbaşı, Melek, “16. Yüzyılda Via Egnatia (1380-1699)”, Sol Kol Osmanlı Egemenliğinde Via Egnatia (1380-1699), ed. Elizabeth A. Zachariadou, çev. Özden Arıkan, Ela Güntekin, Tülin Altınova, İstanbul: Tarih Vakfı Yurt Yayınları, 1999, s. 73-91.

Demircioğlu, Halil, Roma Tarihi Cumhuriyet Birinci Kısım Menşelerinden Akdeniz Havzasında Hâkimiyet Kurulmasına Kadar, Ankara: TTK, 1987.

Dikici, Radi, Bizans Imparatorluğu Tarihi (Şu Bizim Bizans-Byzantium 330-1453), İstanbul: Remzi Kitabevi, 2013.

Kardaras, Georgios, Byzantium and the Avars, 6th-9th Century AD Political, Diplomatic and Cultural Relations, Leiden-Boston: Brill 2018.

Gökbilgin, Tayyip, “Selânik”, I.A., X, MEB Yayınevi, İstanbul 1996, s. 337-349.

Graauw, Arthur de, Ancient Coastal Settlements Port and Harbours, Vol. III / Ancient Port Structures, Grenoble 2020.

Gregory, T.E., Bizans Tarihi, çev. E. Ermet, İstanbul: YKY, 2016.

Günay, Umay Türkeş, Türklerin Tarihi, Ankara: Akçağ Yayınları, 2007.

Hamzaoğlu, Yusuf, “Slovenya'da Avar İzleri”, Türkler, II, Ankara: Yeni Türkiye Yayınları, 2002, s. 687-692.

Hersak, Emil, “Avarlar: Etnik Yaratılış Tarihlerine Bir Bakış”, Türkler, II, Ankara: Yeni Türkiye Yayınları, 2002, s. 641-657.

Jorga, Nicolae, Osmanlı Imparatorluğu Tarihi, İstanbul: Yeditepe Yayınları, İstanbul 2005.

Kafesoğlu, İbrahim, Türk Milli Kültürü, İstanbul: Boğaziçi Yayınları, 1994. 
Karatay, Osman, "Avar Hâkimiyeti ve Balkanların Slavlaşması", Balkanlar El Kitabı, I, ed. Prof. Dr. Bilgehan Atsız Gökdağ, Prof. Dr. Osman Karatay, Ankara: Akçağ Yayınları, 2017, s. 91-98.

Kiel, Machiel, "Selânik", DIA, C. XXXVI, İstanbul: Türkiye Diyanet Vakfı Yayınları, 2009, s. 352-357.

Kurat, Akdes Nimet, IV.-XVIII. Yüzyıllarda Karadeniz Kuzeyindeki Türk Kavimleri ve Devletleri, Ankara: Murat Kitabevi Yayınları, 2002.

Kurat, Akdes Nimet, Rusya Tarihi Başlangıçtan 1917'e Kadar, Ankara: TTK, 1987.

Lemerle, Paul, Les Plus Anciens Recueils Des Miracles De Saint Dèmètrius Et La Pènètration Des Slaves Dans Les Balkans, I, Du Centre De La Recherche Scientifique, Paris 1979.

Maclagan, Michael, The City of Constantinople, London 1968.

Magdalino, P., "Saint Demetrios and Leo Vl”, Byzantinoslavica LI (2), 1990, s. 198-201.

Miller, William, “Selonika”, The English Historical Review, Vol. 32, No. 126, 1917, s. 161-174.

Norwich, J. Julius, Bizans (Erken Dönem M.S. 323-802), I, çev. Hamide Koyukan, İstanbul: Kavalcı Yayınları, 2013.

Ostrogorsky, Georg, Bizans Devleti Tarihi, çev. Fikret Işıltan, Ankara: TTK, 2011.

Pala, Ayhan, XV. ve XVI. Yüzyıllarda Selânik Şehri, Ankara Üniversitesi Sosyal Bilimler Enstitüsü Yayımlanmamış Doktora Tezi, Ankara 1991.

Rance, Philip, "The Fulcum the Late Roman and Byzantine Testudo: the Germanization of Roman Infantry Tactics?", Greek, Roman and Byzantine Studies, 44 (2004), s. 265-326.

Süleymanova, Sevda A., “Kafkasya ve Avarlar”, Türkler, II, Ankara: Yeni Türkiye Yayınları, Ankara 2002, s. 674-686.

Theologou, Kostas-Panayotis G. Michaelides, "The Role of Jews in the Late Ottoman and Early Greek Salonica", Journal of Balkan and Near Eastern Studies, Vol. 12, No: 3, 2010, s. 307-320.

Ünal, Neslihan, İki Osmanlı Liman Kenti İzmir ve Selânik, Ankara: İmge Kitabevi, 2015.

Vickers, M., "Sirmium or Thessaloniki? A Critical Examination of the St. Demetrius Legend", Byzantinische Zeitschrift 67 (2), 1974, s. 337-350.

Whitby, Michael, Essential Histories Rome at War AD 293-696, Osprey Publishing, 2002.

Woods, D., "Thessalonica's Patron: Saint Demetrius or Demeterius?", The Harvard Theological Review 93/3, 2000, s. 221-234.

Zenbilli, Illkgül Kaya, “Aziz Demetrios: Selânik'in Koruyucu Azizi, Yaşam Öyküsü ve Mucizeleriyle iliş̧kili Belgeler, Kültü ve Tasvirleri”, Ortaçağ Araştırmaları Dergisi, Bizans Dosyası, C. 3, S. 2, 2020, s. 361-382. 